\title{
Community-Based Development and Collective Learning: How Does a Local Community Engage and Learn to Initiate a Smart Village Development?
}

\author{
Adi Suryani $^{(1)}$, Soedarso $^{(2)}$ \\ Department of Development Studies, Institut Teknologi Sepuluh Nopember, Indonesia \\ E-mail: (1)adisuryani.rahman@gmail.com, ${ }^{(2)}$ soedarsoits@gmail.com
}

Received: 15 March 2021; Revised: 21 April 2021; Accepted: 5 May 2021

\begin{abstract}
The aim of this study is examining learning process undertaken by Klagen, Nganjuk local community in their journey to transform their rural area into a smart village ad what they need to promote their collective learning. The data are collected through two main methods: community dialogue and direct participant observations during village visits and business training, particularly for Klagen's youth. Thematic analysis, which is grounded on empowerment steps, is performed to interpret the gathered data. Many previous studies examine the outcome of smart village, as the end product. Differently, this study aims to explore the process to develop a smart village, especially at the initial stage and presents development-community education interfaces. The study indicates that to transform their village into a smart village, Klagen community should collaboratively engage in community sharing in which they build shared vision to change, integrate ideas, thinking and social-cultural analysis, observational learning in which they learn from neighbor village model, partnership seeking in which they explore potential networking outside their village area and business-entrepreneurship learning in which the young people learn how to initiate and manage local business.
\end{abstract}

Keywords: community, smart village, rural development, education, empowerment

\section{INTRODUCTION}

Currently, it is not only cities are preparing themselves for industrial revolution 4.0, but also rural areas. The concept of smart is not only applicable for urban, but now it is moving into villages. Some villages start increasing their potential natural and human resources and building capacities to undertake sustainable development. Diverse areas are becoming goals of rural development: tourism, agriculture, agroproducts, e-village and rural entrepreneurship. Rural economic income, social and cultural progress can be potentially increased through these sector development. Transforming rural into a smart village is one of development strategy to achieve rural excellence.
Different village may have different goals and strategies to be smart. Diverse local landscape, nature, social and cultural life and local resource potency can be the determinants of smart village development orientation. In spite of its' abundant rural agricultural products and social-cultural richness, a rural development may not sustain if it is not supported by its' quality human resources. Its' own local people are human asset for development. They are the agents of changes and main drivers of development. Thus, it is significant to increase their competence to develop their own village to reach economical improvement and progress.

This progression will also maintain the village youth, to stay instead of going to city to 
pursue better economic income. The increased urban population from $50.21 \%$ in 2011 to $52 \%$ in 2016is caused by the high mobility from rural to urban since rural people perceive their village as unproductive place (Santoso et al., 2019). Moreover, many urban areas are still neglected in spite of their development issues of poverty, health, women status and environment (de Janvry \& Sadoulet, 2005, p. 75). The lag of income generation and (social) development between urban and rural, in which rurals are left behind in spite of their key roles in development, calls attention. At the International scope, the Millennium Development Goals are related to rural issues (de Janvry \& Sadoulet, 2005, p. $75)$. Specifically, rural development in Indonesia, is supported by UU No. 6, 2016 on rural development. As the result, rural economic growth increases significantly, the number of disadvantaged village decreased from $45 \%$ into $32 \%$ (Santoso et al., 2019). BUMDes (Badan Usaha Milik Desa), as the implication of UU No. 6, 2016, increases sharply into 39.000 in 2018 (Santoso et al., 2019). There are four main village programs focused by Indonesian Rural Ministry: creating and promoting rural competitive product, building water reservoir, developing BUMDes and sport facilities (Subekti \& Damayanti, 2019, p. 3). Many villages are getting smart. It is expected that the smart village concept can re-flow population migration from urban to rural (Shukla, 2016).

This study aims to explore community education aspects towards a smart village development. It is concentrated on how Klagen local community learns together, facilitated by an external developing agent, and what they need during their initial process to transform their village. Many studies on rural development focus on exploring economic development. Less concern is directed to explore process to develop, engagement process, especially towards a smart village development. Secondly, this study highlights interfaces between development and community education. Many educational studies explore classroom learning as well as formal education dimension. This study highlights the social side of education as a tool for improving community well-being. Moreover, it connects the principles of lifelong learning, sustainable development and community livelihood im- provement. It grounds on the preposition that development requires community engagement by learning together. Community education discipline still receive inadequate attention and is still inadequately researched (Department of Education and Science, Ireland, 2000, p. 16).

\section{MATERIALS AND METHODS}

\section{Smart Village: Its' Realm, Urgency and What are Needed to Develop?}

Currently, the concept of smart village is trending and attracts attention. Some areas create rural-based tourism, improve their administration service into e-management and government, or increase the variety of their agricultural products. These phenomena indicate the multidimensionality and multi-faces of smart village. The concept of smart village is created as strategy to advance economic as well as social development achieved through provision of health services, education, clean water and disposal facilities, and sustainable energy for achieving better life, income, safeness, gender rights and opportunities and democratic engagement (Holmes, n.d.). Smart village is a transferred concept from smart city (Subekti \& Damayanti, 2019). It is built up on rural strengths, assets, chance to add product value and enhance traditional methods using technology, innovative ways and new knowledge for its' population welfare (Europian Network for Rural Development, n.d.). In a wider context, smart village also relates to smart environment/ ecosystem, smart energy, smart mobility between village and city, smart technology/digitalization/ digital ecosystem and smart public services (Subekti \& Damayanti, 2019). Community participation is also becomes part of smart village, where rural communities can get their basic humanity rights while maintain the existence of their local culture and wisdom (Subekti \& Damayanti, 2019, p. 19). The variety and heterogeneity of rural natural base, rural societies and social dynamic direct smart villages as a complex notion, instead of a clear-cut definite conception (Zavratnik et al., 2018, p. 2). Thus, different smartness is relied on its' individual community, situation and social circumstances (Zavratnik et al., 2018, p. 2). Since smart village is dependent on its' specific context, a smart village understands its' own unique people, particular advan- 
taged resources, infrastructures and amenities (Shukla, 2016, p. 72).

Why smart village is urgency required in this industrial revolution? Santoso et al, (2019, p. 8) state that smart village may open democracy climate which allow village participation in governance through bottom-up approach and widen networking among villages, stakeholders and government through ICT. Internally, smart village is a method applied to solve rural issues of poverty, disadvantages, social and economical disparities (Miranti et al., 2014).

A number of studies explore several requisites towards successful smart village. Clean and sustainable energy, information, communication and technology, sustainable agricultural eco-system, smart education, health, environment, infrastructure are several basic component of sustainable smart village (NIRDPR, n.d.). Differently, Santoso et al. (2019, p. 14) argue that smart village can be achieved through several dimensions of smart government (participation, transparency and public service), smart economy (innovation and entrepreneurship), smart mobility (transportation, public facility, ICT), smart environment (energy efficiency and environment supervision), smart people (digital education and creativity), smart living (health, security and ICT access), smart tourism (tourism facilities and attraction/ objects). Differently, Gorbenka, Shcherbina and Belal (2018, pp. 787-788) propose several vital rural sustainability drivers and their indicators, including industrial development (indicated by technology and development of built environment), social development (characterized by social capital progression, social supra structure and improving living standards), economic growth (specified by economic heterogeneity, business activities, human capital and budget formation), ecological development (sustainable ecological environment and environment impact) and administrative system development (characterized by improved management systems and resources).

The process of how smart village is built may also determine its success. Planning (Kumar, 2019; Prinsloo et al., 2018), intervention and government concern contribute to the attainment of smart village (Kumar, 2019). Consideration process on rural authenticity of prod- uct, consumption, practices, software, intra- and inter-coherency or how village represents their originality (Frisvoll, 2013), social as well as environment analysis (Anderson et al., 2017) and growth evaluation process (Edwards \& Haines, 2007) are several forming process towards sustainable rural development. Sustainability of rural environment should also become main concern along the process towards smart village. The increasing income of rural inhabitants should not risk or harm their natural environment for long term (Jagustović et al., 2019, p. 74).

\section{Rural Education for Development}

The notion of rural as key of a nation development entails a need to develop villages. Today, villages are not only functioning as urban servers, which are stocking and ensuring urban agricultural fulfillment, but villages can build and grow themselves into diverse types of smart village. Previously, rural development is focused on increasing its' agricultural product, use of wide farmland and agricultural works for raw material provision (Moseley, n.d.). However, recently, villages are shifting from passive recipients into more active shapers and decision makers of their own areas for their own better living (Chigbu, 2013; Cornwall et al., 2000; Ertuna \& Kirbas, 2012; Shaxon, 2011).

These role changes entail that rural inhabitants have equal right to develop and obtain proper education to be skillful. All have rights for education and education is urgently required for building sustainable community (UNESCO, 2011). All people are entitled for education, but what educational types may differ from one person to others and from one society to others. Education for rural development should be practically related to rural agriculture as well as its' natural base strength (Chittoor \& Mishra, n.d.). Rural development today should be considered as mobile and fixed assets development process inter and cross rural and urban areas (Chittoor \& Mishra, n.d., p. 129). Thus, revisited and revised new education curricula are needed to accommodate rural shifted roles. Several elements should be added including social and environment issues concern for sustainable development creation, local knowledge, learning psychology, experiential and participatory learning, skills of inductive reasoning and local community understanding 
(Chittoor \& Mishra, n.d., p. 129). De Janvry and Sadoulet (2005) mention that by learning from rural development program 1970s-1980s run by World Bank and USAID which reached limited success because of declining state roles and structural adjustment, today rural development should be focused on individual and collective initiative from the disadvantaged rural people, based on rural competitiveness, viewed as more than agricultural suppliers, supported by local as well as international policies, addressed as heterogeneous area and social investments, including education, health, women participation. Rural well-being determinants analysis, key entry for rural programs identification, process planning and effective development instrument consideration may lead to rural development success (de Janvry \& Sadoulet, 2005, p. 81).

The urgent need of local people initiative, community participation and analysis of rural competitiveness as well as well-being sector require rural community to be smart community. Rural education is a way to smarten. However, several challenges are frequently impeded rural education, including education access, education quality, community engagement and decentralization, environment-related gender issues, institutional and organizational systems, accommodating non-traditional learners, refining agricultural education, skills from trainings improvements, teachers' recruitment and retention and people-centred policies (Gasperini \& Acker, 2009).

\section{Community Education: Education as Devel- opment Drivers}

Education is the fundamental of development. Carnoy (1999) recommends four educational requirements for encouraging development: education equal opportunities, quality improvement, knowledge effectiveness, physical capital investment availability, innovative and technical competence, structured public administration and education system flexibility.

Poverty in developing countries is frequently linked to education (Filmer, 2000). Loweducated family tends to have low concern on children's education which impacts on their low bargaining power for getting better job and being poor, in return the poverty causes low education (Brown \& Park, 2001). Thus, Education promotes better livelihood through the increasing economic growth and income.

Education is the stimulant of development. Education improves rural economy in several ways: educated workforce can create innovative methods to produce goods and services at local scale and business tends to be established close to places where they can get skilled rural human resources (Gibbs, 2005, pp. 22-23). Education encourages growth of new local enterprises and self-employment at rural (Bosworth, n.d.), reduces rural food insecurity (Gasperini \& Acker, 2009)and minimizes poor and rich people gap (UNICEF, 1992).Moreover, education is not only essential for improving quality of rural workforce for supporting local business, but also impacting on people increased self confidence and participation towards social as well as economic changes (Gasperini \& Acker, 2009). Rural people's identity is also formed by their knowledge gained from education and their development capacity (SIDA, 2000).

\section{Methods}

This is a qualitative study which is grounded on our community service program to empower Klagen rural community towards a smart village. The study is based on the first year of interveneddevelopment program for Klagen empowerment. The program initiative is derived from local people enthusiasm to improve their village capacity building to be able to improve their livelihood: economy, education, tourism and public service.

Desa Klagen Nganjuk is the place where the study is conducted. It is a village which is located in Kecamatan Rejoso, Kabupaten Nganjuk, Jawa Timur. It has 15.24 hectares of agricultural land. Desa Klagen is one of productive village cultivating and providing multi- agricultural commodities: the plantation products, including soybeans, red onion, rice and various types of fruits and vegetables, including sapodilla,banana, guava, mango and papaya, meat, poultry and dairy products, including cow, duck, chicken, egg, rabbit and fisheries products, including cat fish, carp and tilapia. The majority of its inhabitants work in private sectors $(41 \%)$, farmers $(37 \%)$ and farmhands $(9 \%)$ (Kementrian Dalam Negeri Republik Indonesia, 2019; Soedarso et al., 2019). Klagen has several economic business, programs and activities, including rural-owned enterprise, 
credit union, food industry, rural bank, delivery services and other economic sectors (Soedarso et al., 2019). In 2018, in spite of its' multiagricultural products, farming and various economic activities, Klagen is still suffering from rural welfare economic issue since 270 families (22.7\% from total population percentage) are still living in poverty and have only basic ( $42 \%$ finish elementary school), middle education levels (18\% complete junior high schools and 19\% complete senior high school), 37 people are illiterate and 108 people drop out from elementary schools (Kementrian Dalam Negeri Republik Indonesia, 2019; Soedarso et al., 2019).

This condition emerges multi-dimensional issues of lack of educated and skilled human resource and economy. Thus, this study proposes practical skill trainings and education for overcoming human resource issues and boost rural people creativity and innovation which potentially results in increased economy.

The data are collected through the mixedmethods. The mixed-method can accommodate breadth and depth trans-disciplinary of social research (Aitken \& Herman, 2009, p. 7). The first method used is focus group discussion which is attended by the community service team and Klagen local people (the Head of village, youth community/karang taruna, senior inhabitants and educated members). It aims to listen and understand Klagen voices: what they think and feel about their village. The second method is direct natural observation. It aims to examine the real physical condition (access, transportation, technological facilities, culture, trade, and rural people daily activities) of Klagen, explore its' village natural resource potency and competitive advantage, including soybean, banana and garlic plantations. The third method is the entrepreneurial training for Klagen to provide basic knowledge on opening their own businesses. To capture the data, several research instruments are used. Those are notes for quickly write Klagen voices during focus group discussion, cameras to capture images during focus group and direct observation and entrepreneurial training instruments, including pre- and post training short questionnaires and module.

Inductive and thematic analysis is used to examine the collected data. The thematic analy- sis aims to explore themes emerging from the data and inter-linking the data (Feza, n.d., p. 462). The data analysis of the study is conducted in several steps: collecting the data, reading the data, managing the data by sorting, structuring and thematizing, interpreting the data by displaying, describing and linking to the existing studies. All types of qualitative data analysis shared processes of data documentation, categorization, connection, corroboration and representation (Schutt, 2012).

\section{RESULT AND DISCUSSION}

The building of Klagen smart village requires collaborative and collective education of all its' community members. Moreover, synergy among its' local human resource developing capacity, developing partners/agents and local natural potency is needed. This study indicates that the effective and fruitful development synergy is founded and sustained by education, capacity and commitment of Klagen as well as developing partners to collectively learn as rural learning community.

The study shows that in the process to be smart village, there are several learning process should be undertaken. This process requires all, the empowering and empowered community, to learn together.

\section{Learning to share, Local Community Initiative and Participation}

The process towards Klagen smart village is initiated with the focus group discussion. The discussion is more progressing in the format of Musyawarah Desa (rural culture-based dialogue), in which all of the participants are expressing their thinking, expectations, listening, linking and elaborating to each others. This discussion is significant for laying the basis towards smart village learning because of several grounds.

The first is it builds local community or the grassroots initiative, engagement and participation to collectively share what and how their village should develop, progress and determine their development targets. It is expected that this community-based initiative may sustain their village development by evoking people's sense of belongingness and inclusion. The second is it is generating Klagen commitment, motivation and responsibility. The local community should be 
the active and primer developer of their own area. All developing/empowerment agents are just external supporters and facilitators. Klagen internal commitment to develop can result in development loyalty. Participation links to loyalty and attachment (Zhang et al., 2013). Successful community development is grounded on community-initiative approach in which the community is engaged to make changes for their future (Community Development, n.d., p. 5). This collective learning is implications of Klagen needs to adapt to the changing environment, as they feel the need to improve their economy and competitiveness for not being left behind from the neighbor villages and self preparation for welcoming great irrigation building close to Klagen. Learning is a survival action to adapt to changing environment (Schunk, n.d., p. 348).

The community sharing also allows the accommodation of collective aspiration, community needs and implicit challenges. This is as represented in Table 1. Besides expressing aspirations, the community sharing enables them to map their rural challenges, as represented in Table 2 .

The community sharing reflects collective learning which brings about a collective plan formulation, shared community vision and shared rural leadership. The development of Klagen is not only the responsibility of its' rural leaders, instead it is shared by all community. Learning communities are indicated by shared vision, dialogue, shared leadership and support-

Table 1. Community aspiration and needs

\begin{tabular}{|l|l|}
\hline $\begin{array}{c}\text { Community } \\
\text { members }\end{array}$ & \multicolumn{1}{|c|}{ Aspiration and needs } \\
\hline $\begin{array}{l}\text { Head of } \text { Kla- } \\
\text { gen Village }\end{array}$ & $\begin{array}{l}\text { Improving public service, online admin- } \\
\text { istration, village re-structure, communi- } \\
\text { ty development, education, professional } \\
\text { administration education, information } \\
\text { transparency, rural centre of finance }\end{array}$ \\
\hline $\begin{array}{l}\text { Senior mem- } \\
\text { bers }\end{array}$ & $\begin{array}{l}\text { Improving agricultural product market- } \\
\text { ing, rural center of finance, promotion } \\
\text { of } \text { nyadran cultural tradition, rural park, } \\
\text { proposal training for getting funding }\end{array}$ \\
\hline Youth & $\begin{array}{l}\text { Young journalism trainings, digital } \\
\text { business, technological trainings, in- } \\
\text { cluding photoshop, video editing, rural } \\
\text { web, documentary film, web-based in- } \\
\text { formation system, wi-fi access and base } \\
\text { camp }\end{array}$ \\
\hline
\end{tabular}

Table 2. Perceived local challenges

\begin{tabular}{|c|c|}
\hline $\begin{array}{c}\text { Klagen Life As- } \\
\text { pects }\end{array}$ & Challenges \\
\hline Mobility & $\begin{array}{c}\text { The population has high mobility to } \\
\text { move from their village to cities }\end{array}$ \\
\hline $\begin{array}{c}\text { Local govern- } \\
\text { ance }\end{array}$ & Lack of administrative staff \\
\hline $\begin{array}{c}\text { Economic barrier } \\
\text { The majority of Klagen are farmers and } \\
\text { do not have any other occupations and } \\
\text { economic income as supplementary in- } \\
\text { come when they are waiting for harvest }\end{array}$ \\
\hline Youth Business & Decreasing or bankrupt \\
\hline
\end{tabular}

ive culture (Verbiest et al, 2004, cited in Verbiest et al., 2005). The collective learning through community sharing also indicates Klagen situational analysis on their village weakness, potency and future prospect. They are aware of the need to change, innovate and be aware of the globalization and modernity needs and threats. Klagen collective learning is one of several applications of social learning constructivism. The intersection of various perspectives and integrated views can be reached through this collective learning. Social constructivism emphasizes the role of social interaction for skill and knowledge building (Schunk, n.d., p. 230). Moreover, the constructivism believes that individual constructs knowledge from interaction with other people, environment, experiences, models and external world (Schunk, n.d.).

\section{Learning from other villages}

The other learning process towards Klagen smart village is learning from other villages which are successful or have undertaken similar process or experience. Several villages which develop eco- and edu-rural tourism become Klagen learning models. Those villages or rural tourism destinations are Kampung Sejuta Ikan, Desa Wisata Jambu,andWisata Air Gronjong Wariti. They are located at different kabupaten from Klagen. Besides observing villages outside Kabupaten Nganjuk, Klagen learns from their successful neighbor village, Desa Rejoso. Formerly, Desa Rejoso was less developed from Klagen, but now it is becoming more developed village because of its' Mataraman culinary tourism (which can be model of business venture at small scale), agricultural-based local business and effective rural financial management. 
The observational learning is not only undertaken for examining successful rural tourism, but also decreased destination. Kampung Salak Griyo Asriand its' Taman Bunga become lived models for learning some aspects causing unsustainable rural tourism destination. Learning also occurs by observing other people behavior and its consequences (Bandura, 1971, p. 2).

By observing the model village, Klagen and the community service team learn several principle aspects of smart village creation. The first aspect is exploring and identifying village natural potency for Klagen smart village advantage competitiveness. Secondly, sustainable smart village requires participation and engagement of its' own community to sustain and develop their own village. The development agents will leave the developed village as they finish the programs. Thirdly, model learning allows Klagen to re-build and re-complete smart village shared vision, what type of smart village or rural tourism they want to create or focus in the future, what are Klagen village-uniqueness based tourism. Fourthly, Klagen smart village needs quality human education which can be built through collective community learning. Klagen observational learning indicates that learning from model does not mean imitating or copying the model entirely, instead Klagen fits what may work in their own environment. Human action and development is influenced by their schemas, which are built from their prior experiences and knowledge (Schunk, n.d., p. 124). Engagement, observation, reproduction and reinforcement are several principles ensuring effective observational learning (Morse, 2017, pp. 6-8). Paying attention, storing and recalling, motivating and reproducing are also learning elements in modeling learning (Schunk \& Zimmerman, 1997).

\section{Building Partnership and Collaboration with External Agents}

Learning towards Klagen smart village is a social quest and learning. It needs all the learners to collectively craft knowledge from different experts and other people or communities. Having ideas as well as initiatives only is not adequate. Klagen local community needs to network, build partnership and collaboration with external practitioners, agency/non government and government institutions and stakeholders. A successful community development program is not the work result of an individual or several individuals, instead it is created from collaborated and networked teams (Community Development, n.d.).

During the process of smart village creation, Klagen builds potential partnership with Local Department of Tourism for Kabupaten Nganjuk (prospective community-local government partnership). The partnership is at the initial stage of exploring local government tourism programs which are potentially inherent with Klagen plan to create edu- and eco-tourism in the following year. The prospective partnership with local tourism department indicates joint initiatives and responsibility since the partner side is also responsible for developing tourism at local Nganjuk scale. Effective partnership is built through shared vision, passions, clear goals, respect and trust, curiosity, intention to learn from each other and effective communication (Estacio et al., 2017). The second is building partnership with an independent practitioner for krupuk (cracker) making training. This training is expected to be starting business to open other agricultural-based business. Partnership allows learning from cocreation (International Development Services (IDAS), 2016). The third is community-higher education partnership for entrepreneurial education for Klagen community, targeting specifically for the youth. Several higher education students majored at Business Management share their business knowledge with Klagen. Partnership, networking and collaboration allows the achievement of maximum results by providing complementary knowledge, skills and experiences from diverse partners (Estacio et al., 2017, p. 4), increased problem solving of environmental, social and economic issues (Coetzee, 2014). Moreover, partnership helps the empowered community to be more focus on their development (The Institute for Educational Leadership, n.d.).

Klagen smart village process involves various stakeholders: community-university, community-practitioner and potential community-local government. This identifies a collaborative community development as effective collaborative community development involves various stakeholders, build constructive and recurrent collaboration, set long focus and is integrated as a whole 
system (Network for Business sustainability, 2017). Bridging Klagen smart village partners is a challenging process. Partnership is a dynamic process (OECD LEED, 2006, p. 9). Limited budget and prospective partner refusal are some challenges in Klagen partnership building. Funding and policy changes may endanger the partnership sustainability (Israel et al., 2006).

\section{Entrepreneurship Training}

The other Klagen learning towards a smart village is the entrepreneurial learning for youth or karang taruna (community-based youth organization). It is expected that entrepreneurial skills can result in multiple-impacts of growing economy through agribusiness, improved quality and quantity of agricultural and opening eduand eco-rural tourism. Entrepreneurs create employment, increased competition and productivity (Acs, 2006, p. 97), entrepreneurship as main machine of economic development (Ahmad et al., 2012), rural development process accelerator (Saxena, 2012, p. 23) and sustainable development protection (Lordkipanidze et al., 2005, p. 790). Vocational skills followed by effective values, attitudes and knowledge can increase income (UNESCO Principal Regional Office for Asia and the Pacific, 1993, p. 6). The targeted participants are Klagen youth. Klagen has 25 young people who live in Klagen, and do not pursue their studies into higher education. Thus, they are expected to be young pioneers, keep on staying in Klagen to develop their villages, instead of mobile to urban areas and getting knowledge to learn and re-awake their previous business failure.

This training is an intervention program to engage Klagen youth and participation to create village business, which is based on Klagen shared interest and its local natural resource potency, red onion and soybean. The training is divided into 2 main sections: introducing basic concept of entrepreneurship to create smallscale agribusiness and making krupuk, for adding commercial values of agricultural raw material. Locality (local individual, resources and information) is the key consideration of entrepreneurial process (Kalantaridis \& Bika, 2006; Nwankwo \& Okeke, 2017). To be effective, rural entrepreneurship should consider its' local resources, local people occupation and six-m (money, management, material, machinery, manpower, market) system (Patel \& Chavda, 2013, p. 29).

Through this training, Klagen youth are introduced some business aspects, including business introduction: how to find, explore and manage agricultural potency at Klagen, financial management: seeking money sources and accounting, and marketing: packing product and marketing. Financial and marketing are frequent obstructions found in rural entrepreneurship (Patel \& Chavda, 2013). The other barrier is lack of skills which prohibit them to fir into available jobs (Dabson, n.d.). Thus, creating employment using their specialized skills may help.

\section{Learning beyond Classroom, Lifelong Learning and Community Education}

Klagen smart village is a continual development process. Along this process, community education is required as education can enable, acknowledge and empower Klagen community as main development drivers. Thus, education is a key in development.

Klagen smart village indicates a need for community lifelong learning. Together, they are aware that they need to learn again to respond to environmental changes and improve their livelihood and well-being. Education needs may arise because of life necessity. Lifelong learning should be shifted from learner-centred into learner-driven (Ministry of Higher Education Malaysia, 2011, p. 4). Thus, it should be driven by Klagen community.

Klagen life demands trigger its' people/ community to undertake continual learning, even after their school-age period. Their economy need and intention to be developed village motivate them to change. This is because globalization forces social-economic landscape changes today (Ministry of Higher Education Malaysia, 2011, p. 3)and lifelong learning is a principle way to adapt to rapid changing (Hanemann, 2016, p. 16). Smart village learning as a learning beyond classroom signifies that learning is universal, timeless and limitless. Flexible delivery system, dynamic and pedagogy should be embraced by today community educators (Ministry of Higher Education Malaysia, 2011, p. 4). Through smart village, it is expected that more job/employment can be created in Klagen. Lifelong learning relates to social, 


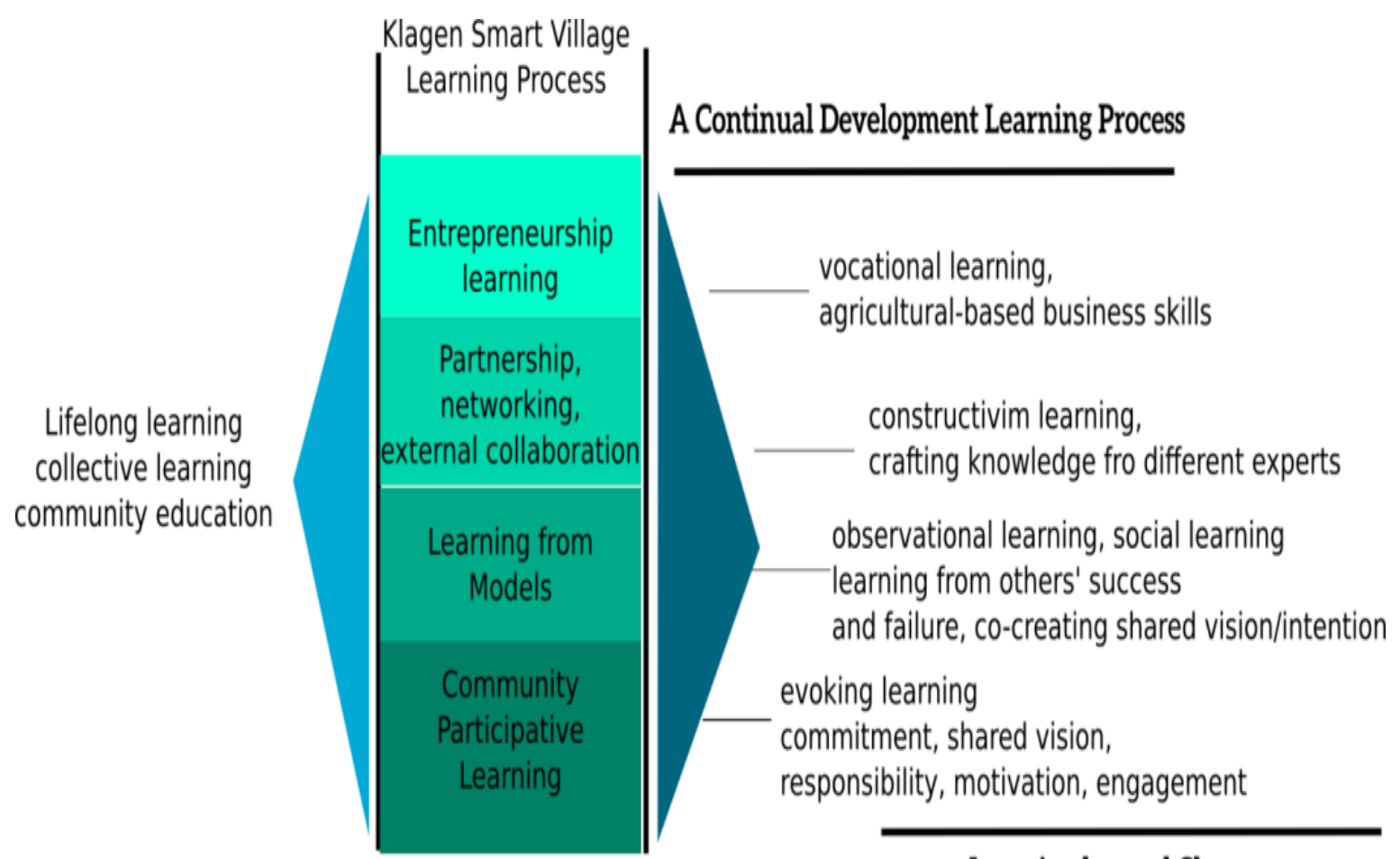

Learning beyond Classroom

Figure. 1. Klagen learning process towards a smart village (at the beginning stage)

national development (Biney \& Okai-Mensah, 2017), life earning (The economist, 2017) and learning and living (UNESCO, n.d.).

Figure 1 shows several continual learning towards a smart village. It involves combined types of learning: participative, observational, constructivism and entrepreneurial learning. It is framed into community lifelong learning education.

Klagen smart village learning fits into lifelong learning framework. Lifelong learning is characterized by learning to be, learning to know, learning to do and learning together (UNESCO, n.d.). In Klagen smart village, learning to be is represented by the community strong intention to change their village from ordinary into smart village. They learn how to open agribusiness and transform their village into tourism destination represents learning to know. They are learning and practicing to make krupuk is the action for learning to do. They are performing collective learning is the learning to live together.

\section{CONCLUSION}

Building a smart village needs collaborative participation and learning of all community members. Klagen, a village in Kabupaten
Nganjuk, intends to transform their village into a smart one. At the beginning stage (the first year), they should engage in integrated learning process. The participative and sharing learning process aims to analyze their local potency and collectively envision their potential smart village. Through modeling learning, Klagen can observe and learn from certain models on how to be successful smart village as well as what may deteriorate existing smart village. Partnership and external collaboration learning allows to learn by crafting knowledge from diverse experts and building their own version. The entrepreneurship learning allows them to acquire practical skills on initiating and managing agricultural-based rural business. These learning should be undertaken collectively and life long since smart village creation is a continual development.

\section{ACKNOWLEDGMENTS}

The authors are really grateful to Pak Kades (head village), community representatives, women, karang taruna (local youth association) and all of Klagen community for welcoming, trusting and working collaboratively and cooperatively with the authors, participating and learning together for being better and self-sustained community. We also wish to thank PDPM-LPPM-ITS for supporting the authors' endeavors to empower 
rural community by providing funds and facilities. The authors would like to express gratitude to some students of Managemen Bisnis/MB, ITS, Aisyah, Sarah, Belia and Lukman Ali for their care, deep concern on community life empowerment and contribution to the program.

\section{REFERENCES}

Acs, Z. (2006). How Is Entrepreneurship Good for Economic Growth? Innovation, 97107.

Ahmad, A. R., Yusoff, W. F. W., Noor, H. M., \& Ramin, A. K. (2012). Preliminary study of rural entrepreneurship development program in Malaysia. Journal of Global Entrepreneurship, 2(1), 1-8.

Aitken, S. C., \& Herman, T. (2009). Literature review on qualitative methods and standards for engaging and studying independent children in the developing world (Innocenti Working Paper IWP-2009-05; pp. 1-62). UNICEF Innocenti Research Centre.

Anderson, A., Loomba, P., Orajaka, I., Numfor, J., Saha, S., Janko, S., Johnson, N., Podmore, R., \& Larsen, R. (2017). Empowering Smart Communities: Electrification, Education, and Sustainable Entrepreneurship in IEEE Smart Village Initiatives. IEEE Electrification Magazine, 6-16.

Bandura, A. (1971). Social learning theory. General Learning Press.

Biney, I. K., \& Okai-Mensah, C. K. (2017). Lifelong learning and national development: The case of Ghana. International Journal of Development and Sustainability, 6(7), 333-349.

Bosworth, G. (n.d.). Education, mobility and rural business development (pp. 1-30) [Research Paper].

Brown, P., \& Park, A. (2001). Education and poverty in rural China. Forthcoming in the Economics of Education Review.

Carnoy, M. (1999). Globalization and educational reform: What planners need to know. Paris, France: UNESCO, International Institute for Educational Planning.

Chigbu, U. E. (2013). Fostering rural Sense of place: The missing piece in Uturu, Nigeria. Dev. Pract, 23(2), 264-277.

Chittoor, J. S., \& Mishra, S. K. (n.d.). Agricul- tural Education for Sustainable Rural Development in Developing Countries: Challenges and Policy Options. Journal of Education and Learning, 6(2), 119-132.

Coetzee, C. (2014). Successful Partnerships for Economic Development. https:// www.researchgate.net/ publication/271967113

Community Development. (n.d.). Coming Up with the Money. Five Principles for Launching a Successful Community Development Initiative (pp. 1-43). Community Development department of the Federal Reserve Bank of St. Louis. stlouisfed.org/community -development CD15-4

Cornwall, A., Lucas, H., \& Pasteur, K. (2000). Introduction: Accountability through participation: Developing workable partnership models in the health sector. IDS Bull, 31(1), $1-13$.

Dabson, B. (n.d.). Supporting Rural Entrepreneurship. 35-47.

de Janvry, A., \& Sadoulet, E. (2005). Achieving Success in rural development: Toward implementation of an integral approach. $R e$ shaping Agriculture' Contributions for Society, 75-89.

Department of Education and Science, Ireland. (2000). Learning for Life: White Paper on Adult Education. Stationery Office, Dublin.

Edwards, M. M., \& Haines, A. (2007). Evaluating Smart Growth Implications for Small Communities. Journal of Planning Education and Research, 27, 49-64. https:// doi.org/DOI: 10.1177/0739456X07305792

Ertuna, B., \& Kirbas, G. (2012). Local community involvement in rural tourism development: The case of Kastamonu, Turkey. PASOS, 10(2), 17-24.

Estacio, E. V., Oliver, M., Downing, B., Kurth, J., \& Protheroe, J. (2017). Effective Partnership in Community-Based Health Promotion: Lessons from the Health Literacy Partnership. International Journal of Environmental Research and Public Health, 14 (1550), 1-8. https://doi.org/doi:10.3390/ ijerph14121550

Europian Network for Rural Development. (n.d.).

Feza, N. N. (n.d.). Chapter 25. Qualitative data analysis. In Planning, designing and conducting educational research (pp. 456-474). 
Filmer, D. (2000). The structure of social disparities in education [World Bank Policy Research Working Paper No. 2268]. World Bank.

Frisvoll, S. (2013). Conceptualizing authentication of ruralness. Annals of Tourism Research, 43, 272-296. http:// dx.doi.org/10.1016/j.annals.2013.07.006

Gasperini, L., \& Acker, D. (2009). Education for Rural People. The Role of education, training and development in poverty and food security. FAO. ISBN: 978-92-5$106237-1$

Gibbs, R. (2005). Education as a Rural Development Strategy (pp. 20-25) [Amber Waves]. Economic Research Service/ USDA. WWW.ERS.USDA.GOV/ AMBERWAVES

Gorbenkova, E., Shcherbina, E., \& Belal, A. (2018). Rural areas: Critical drivers for sustainable development. IFAC PaperOnline, 51(30), 786-790. https://doi.org/ doi:10.1016/j.ifacol.2018.11.195

Hanemann, U. (2016). Shaping the literacy agenda from a lifelong learning perspective. Adult Education and Development, 83, 14-17.

Holmes, J. (n.d.). The smart villages Initiative: Findings 2014-2017. https://e4sv.org/ publication/smart-villages-initiativefindings-2014-2017/

International Development Services (IDAS). (2016). Unlocking the power of partnership. A framework for effective crosssector collaboration to advance the global goals for sustainable development (pp. 233). KPMG International.

Israel, B., Krieger, J., Vlahov, D., Ciske, S., Foley, M., Fortin, P., \& Tang, G. (2006). Challenges and facilitating factors in sustaining community-based participatory research partnerships: Lessons learned from the Detroit, New York city and Seattle urban research centers. J. Urban Health Bull. N. Y. Acad. Med, 83, 1022-1040.

Jagustović, R., Zougmoré, R. B., Kessler, A., Ritsema, C. J., Keesstra, S., \& Reynolds, M. (2019). Contribution of systems thinking and complex adaptive system attributes to sustainable food production: Example from a climate-smart village. Agricultural
Systems, 171, 65-75. https://

doi.org/10.1016/j.agsy.2018.12.008

Kalantaridis, C., \& Bika, Z. (2006). Local embeddedness and rural entrepreneurship: Case -study evidence from Cumbria, England. Environment and Planning, 38, 1561-1579.

Kementrian Dalam Negeri Republik Indonesia. (2019). Data Pokok Desa/Kelurahan.

Direktorat Jenderal Bina Pemerintahan Indonesia. http://

prodeskel.binapemdes.kemendagri.go.id/ pokok-grid-t01

Kumar, A. (2019). Beyond technical smartness: Rethinking the development and implementation of sociotechnical smart grids in India. Energy Research \& Social Science, 49, 158168. https://doi.org/10.1016/ j.erss.2018.10.026

Lordkipanidze, M., Brezet, H., \& Backman, M. (2005). The entrepreneurship factor in sustainable tourism development. Journal of Cleaner Production, 13, 787-798. https:// doi.org/doi:10.1016/j.jclepro.2004.02.043

Ministry of Higher Education Malaysia. (2011). Blueprint on enculturation of lifelong learning from Malaysia 2011-2020 (pp. 1-69, Published by: Univision Press sdn.Bhd). Ministry of Higher Education Malaysia.

Miranti, R., Duncan, A., \& R., C. (2014). Revisiting the Impact of Consumption Growth and Inequality on Poverty in Indonesia during. Decentralisation. Bulletin of Indonesian Economic Studies, 50(3), 461-482. https:// doi.org/10.1080/00074918.2014.980377

Morse, B. A. B. (2017). The role of observational learning in developing ecotourists' environmentally responsible behavioural intentions [A master degree thesis].

Moseley, M. J. (n.d.). Rural development. Principles and practice. SAGE.

Network for Business sustainability. (2017). Collaborative Community Development: A Guide for Managers. Network for Business Sustainability. https://www.nbs.net/articles/ collaborative-community-development-aguide-for-managers

NIRDPR. (n.d.). Mainstreaming smart village in rural development: A framework for analysis and policy. 